\title{
DECLARATIVE MOOD OF IDEATIONAL THEME IN “EXUPERY'S THE LITTLE PRINCE: A FUNCTIONAL GRAMMAR ANALYSIS
}

\author{
Yulia Istiqomah \\ English Department of UNIKOM \\ Istiyulia36@gmail.com
}

\begin{abstract}
This research entitled "Declarative mood of Ideational Theme in "Exupery's The Little Prince" (A Functional Grammar Analysis) discusses declarative mood in ideational theme in the position of clause used in novel. The purpose of this research is to analyze declarative mood and to analyze the constituents used in the novel The Little Prince. To analyze the issues, this research uses the theory of mood types: declarative mood by M.A.K Halliday and Christian Matthiessen (2004) as the grand theory while Linda Gerot dan Peter Wignell (1994) as supporting theory. The method used in this research is descriptive analysis. Data are taken from the novel The Little Prince by Antoine de Saint Exupery. After analyzing the data, it can be concluded that the all data are included into the declarative mood in this research, two data are included into constituent the nominal group as theme, and one data is included include into constituent prepositional phrase as theme in this research.
\end{abstract}

Keyword : Declarative mood, Constituent.

\section{Abstrak}

Penelitian ini berjudul "Declarative Mood pada Ideational Theme dalam "The Little Prince" karya Antoine De Saint Exupery" (Analisis Fungsional Grammar)menjelaskan declarative mood dalam ideational theme yang terdapat pada klausa yang digunakan dalam novel. Tujuan dari penelitian ini adalah untuk menjelaskan declarative mood apa saja yang menempati ideational theme dan untuk menjelaskan konstituen apa saja yang membangun mood tersebut dalam novel "The Little Prince". Untuk menganalisis permasalahan, penelitian ini menggunakan teori mood types: declarative mood oleh M.A.K Halliday and Christian Matthiessen (2004) sebagai teori utama. sedangkan teori dan dari Linda Gerot dan Peter Wignell (1994) sebagai teori pendukung. Metode yang digunakan peneliti adalah metode deskriptif. Data yang digunakan berasal dari novel "The Little Prince" karya Antoine de Saint 
Exupery. Setelah menganalisis data pada declarative mood, bisa disimpulkan bahwa semua data termasuk kedalam tipe tema topikal pada penelitian ini, dua data termasuk dalam nominal group sebagai tema, dan satu data termasuk dalam prepositional phrase sebagai tema.

Kata Kunci: Declarative Mood, Konstituen.

\section{INTRODUCTION}

Mood systems in functional grammar have two types of mood. Two types of mood are indicative mood and the imperative mood. In this case, this article focuses on the types of mood in the form of indicative mood. The indicative mood is divided into two: the declarative mood and interrogative mood. In this article, the writer focuses on declarative mood. Mood was built by two elements, namely subject and finite. "Mood in English is realized by the position in the clause of the subject and finite" (Gerot and Wignell.1994:38). Based on the theory Gerot and Wignell (1994) in all types of mood can be analyzed in the clause of the subject and finite. Both of these elements build declarative mood. The constituents that build the subject have a diversity of constituents. Finite that builds mood tenses aspects indicate that mood can simply show how a clause is built by constituents and provide an indication of the interest of constituents that appear.

The importance of mood in this research because each constituent that builds mood clause produce different indications. The type of mood discovered in this research is declarative mood. This issue had been discussed previously in Faculty of Letters at Indonesia University of Computer. The First research entitled "The Use of Theme and Rheme in Sentences in Brochures Tour and Travel Itinerary Destined Vietnam" was written by Wiyogi Sanhaji, 2014. The data of the research is the brochures tour and travel itinerary destined Vietnam from MUSTAFA AIR TRAVEL PTE LTD Singapore. It focuses that theme is not included in the sentences of brochures tour and travel and describes the form of theme in the clause. Thesecond research was written by Anistya Rachmawati,2010, entitled "Thematic Progression in Gail B. Stewart's Cuba (Places in the News)" . This research is intended to describe the types of thematic progression applied in the narrative text and to discover the cohesion devices used to maintain the progression of the theme. This research shows how the progression of a theme or rheme of one clause is taken as the theme of the following clause by the aid of cohesion devices to gain the texture of the text. However, the writer more focuses mood types in declarative mood and constituent. Therefore, this research is entitled "Declarative mood of 
Ideational Theme in "Exupery's The Little Prince": (A Study of Functional Grammar)

\section{DATA SOURCE}

In this study, the data source is taken from the novel "The Little Prince" by Antoine de Saint Exupery. The novel was published by Houghton Mifflin Harcourt Publishing Company in 1971 in Boston New York. The object of this research is mood that is declarative mood. The researcher chooses that Novel as the data source since the selected data indicates declarative mood. In the data source, mood contained in the data consist of declarative mood. This data are discovered on the various constituents in the declarative mood

\section{METHOD}

The writer used descriptive method described by Sugiyono (2008):

"Metode Deskriptif Analisis merupakan metode penelitian dengan cara mengumpulkan data-data sesuai dengan yang sebenarnya kemudian data-data tersebut disusun, diolah dan dianalisis untuk dapat memberikan gambaran mengenai masalah yang ada". ( Sugiyono.2008:105)

Based on the theory above, the writer conclude that the descriptive method used in this research is to describe the data that have been classified in accordance with the theory used to further systematically explained. It can be seen on data taken from the novel, which then is classified as declarative mood.Thus, the results of the analysis can describe the condition of the data as it is.

\section{THEORETICAL REVIEW}

In this article, several theories are used to analyze the data. The data found are analyzed using the theories of mood by M.A.K Halliday and Christian Matthiessen (2004) as the grand theory and Linda Gerot and Peter Wignell (1994) as the supporting theory. It is said that "Mood consists of two essential constituents, they are Subject and Finite" (Halliday p.76) and the other theory from Gerot and Wignell (1994) "Mood in English is realized by the position in the clause of the subject and finite" (Gerot and Wignell p.38)

According to the theory from Halliday and Gerot Wignell, There are two components of what Halliday calls mood, namely: the subject and finite. Then, According to Gerot and Wignell (1994, p.104), ideational or known as topical 
theme is usually, not always, realized by nominal group which comes first in the clause. It can also be realized by nominal group complex, adverbial group, and prepositional phrase which come first in the clause.

In relation to that, this research uses theory of mood by Hallidan and Christian Matthiessen. Mood is defined as interpersonal because there is an exchange within clause. Therefore, clause exchange relates to mood and residue which indicates types of mood. Mood is divided into two parts, the indicative mood and imperative mood. Indicative mood is differentiated into declarative and interrogative, while declarative mood is realized by the feature of subject + finite. The imperative mood element may not have subject and finite and only has residue. Mood is a system through which interpersonal meanings are realized within the conversation. It consists of two parts: the subject, which is a nominal group, and the finite operator, which is part of a verbal group, and the remainder of those parts are called residue. The Residue consists of Predicator, Complement, and (Circumstantial) Adjunct. The Constituents of residue are: predicator which is the lexical or content part of the verbal group, complement which is defined as a non-essential participant in the clause, a participant somehow effected by the main argument of the proposition, and adjuncts which are clause elements that contribute some additional information to the clause. They can be identified as elements which do not have the potential to become Subject. They are not nominal elements, but are adverbial, or prepositional. Circumstantial adjuncts. Modal adjuncts are mood adjunct \& polarity adjuncts (yes or no), \& comment adjuncts, vocative adjuncts. Textual Adjuncts are conjunctive adjuncts and continuity adjuncts.

\section{FINDINGS AND DISCUSSIONS}

\section{Data 1}

I waited a long time

\begin{tabular}{|l|l|l|l|}
\hline I & \multicolumn{1}{|c|}{ did } & \multicolumn{1}{c|}{ wait } & a long time \\
\hline Subject & Finite & Predicator & Adjunct \\
\hline \multicolumn{2}{|c|}{ Mood Element } & Residue Element \\
\hline Nominal group & & \\
\hline Ideational theme & Rheme \\
\hline $\begin{array}{c}\text { Unmarked } \\
\text { Theme }\end{array}$ & & \\
\hline
\end{tabular}

On the data 1 above, I as unmarked theme and waited a long time as rheme. Mood types shown in the data is indicative mood in the form of declarative because it has the subject in the form of unmarked theme and did 
as the finite with the primary past tense in the clause .Residue element are predicator wait and adjunct a long time in the clause. The constituents that build the declarative mood on this data is in the form of nominal group "he" occupies a subject pronoun and the clause build mood.

\section{Data 2}

I lived in many big people

\begin{tabular}{|l|l|l|l|}
\hline$I$ & did & Live & $\begin{array}{l}\text { in many big } \\
\text { country }\end{array}$ \\
\cline { 1 - 3 } Subject & Finite & Predicator & complement \\
\hline Mood Element & \multicolumn{3}{|l|}{ Residue Element } \\
\hline Nominal group & & & \\
\cline { 1 - 2 } $\begin{array}{l}\text { Ideational } \\
\text { theme }\end{array}$ & & \\
\cline { 1 - 2 } $\begin{array}{l}\text { Unmarked } \\
\text { Theme }\end{array}$ & Rheme & \\
\hline
\end{tabular}

On the data 2 above, I lived in many big people. I as unmarked theme and lived in many big people as rheme. Mood types shows data is indicative mood in the form of declarative, it is because I has the subject in the form of unmarked theme and did as the finite with the primary past tense in the clause. Residue element of this research predicator and complement. Constituents that build declarative mood on this data is in the form of nominal group I as a subject as pronoun.

\section{Data 3}

He was really angry

\begin{tabular}{|l|l|l|l|}
\hline He & Was & really angry \\
\hline Subject & Finite & Predicator & Complement \\
\hline Mood Element & \multicolumn{3}{|}{ Residue Element } \\
\hline Nominal group & \\
\cline { 1 - 1 } Ideational theme & \\
\cline { 1 - 2 } Unmarked Theme & \multicolumn{2}{|}{ Rheme } \\
\hline
\end{tabular}

On the data 3 above, He was really angry. He as unmarked theme and was really angry as rheme. Mood types shows data is indicative mood in the form of declarative, it is because he has the subject in the form of unmarked 
theme and was as the finite with the primary past tense in the clause. Element of residue in this clause is predicator was and complement really angry. Constituents that build declarative mood on this data is in the form of nominal group He as a subject as pronoun.

\section{Data 4}

You confuse everything

\begin{tabular}{|l|l|l|l|}
\hline You & Are & Confuse & Everything \\
\hline Subject & Finite & Predicator & Adjunct \\
\hline Mood Element & \multicolumn{3}{|l|}{} \\
\hline Nominal group & & \\
\hline Ideational Theme & & \\
\hline Unmarked Theme & Rheme & \\
\hline
\end{tabular}

In the data above, you confuse everything, You as unmarked theme and confuse everything as rheme. Mood types shows data is indicative mood in the form of declarative, it is because You has the subject in the form of unmarked theme and are as the finite with the primary present tense in the clause. The element of residue in the clause is predicator "confuse" and "everything" adjunct. Constituents which build declarative mood on this data is in the form of nominal group you as a subject as pronoun.

\section{CONCLUSION}

Based on the analysis, it can be concluded that, this article is aimed to find declarative mood in novel The Little Prince by Antoine De Saint Exupery. The writer found mood types that is declarative mood in ideational theme. In addition, in 4 (four) data is declarative mood, the writer found that the constituent build the mood is a nominal group as a theme, In summary, mood types that appears in the novel is declarative mood.

\section{REFERENCE}

Exupéry De Saint, Antoine. 1971. The Little Prince. New York: Houghton Mifflin Harcourt Publishing Company

Gerot, Linda. and Peter Wignell. 1994. Making Sense of Functional Grammar. Sydney: Great Stabler

Halliday M.A.K. and Christian Matthiessen. 2004 An Introduction to Functional Grammar. $3^{\text {rd }}$ edn. (London: Edward Arnold) 
Rachmawati, Anistya. 2010. Thematic Progression in Gail B. Stewart's Cuba (Place in The News). Bandung: UNIKOM.

Sanhaji, Wiyogi. 2014. "The Use of Theme and Rheme in Sentences in Brochures Tour and Travel Itinerary Destined Vietnam". Bandung:UNIKOM.

Sugiyono. 2008. Metode Penelitian Bisnis. Cetakan keduabelas. Bandung: CV. Alfabeta. 